\title{
Application of a multiplex PCR genotyping assay of 31 red blood cell antigens for establishment of a panel of reference DNA in China
}

\author{
Yuping Chen ${ }^{1}$, Tongmao Zhao ${ }^{2 *}$ \\ ${ }^{1}$ Jiangsu LIBO Medicine Biotechnology Co., Ltd., Jiangyin, Jiangsu, 214400, China; \\ ${ }^{2}$ National Institutes of Health, Bethesda, Maryland, 20852, USA
}

\begin{abstract}
DNA based blood group genotyping has been widely used in clinical blood transfusions, and a number of different molecular blood group testing methods have been developed, including the detection of single nucleotide polymorphism (SNP) and genomic DNA sequencing. As the molecular bases of blood groups can differ widely between ethnic groups, a set of reference DNAs, especially for the Chinese population, is required for the development and validation of these methods, and for their optimal use in routine practice in China. In this study, a total of 100 DNA samples obtained from 60 established cell lines and 40 Chinese blood donors were typed for 31 red blood cell antigens of 13 blood group systems using a multiplex polymerase chain reaction (PCR) assay. Finally, nine DNA samples were selected to establish a panel of reference DNA that included $\mathrm{M}, \mathrm{N}, \mathrm{S}, \mathrm{s}, \mathrm{Mur}, \mathrm{Lu}^{\mathrm{a}}, \mathrm{Lu}^{\mathrm{b}}$, $\mathrm{Au}^{\mathrm{a}}, \mathrm{Au}^{\mathrm{b}}, \mathrm{K}, \mathrm{k}, \mathrm{Fy}^{\mathrm{a}}, \mathrm{Fy}^{\mathrm{b}}, \mathrm{Jk}^{\mathrm{a}}, \mathrm{Jk}^{\mathrm{b}}, \mathrm{Di}^{\mathrm{a}}, \mathrm{Di}^{\mathrm{b}}, \mathrm{Sc}, \mathrm{Sc} 2, \mathrm{Do}^{\mathrm{a}}, \mathrm{Do}^{\mathrm{b}}, \mathrm{Co}^{\mathrm{a}}, \mathrm{Co}^{\mathrm{b}}, \mathrm{Kn}^{\mathrm{a}}, \mathrm{Kn}^{\mathrm{b}}, \mathrm{In}^{\mathrm{b}}$, Vel antigens and Fy(a-b-) null phenotype.
\end{abstract}

Keywords: blood group genotyping, multiplex PCR, reference DNA, Chinese population

\section{INTRODUCTION}

The International Society of Blood Transfusion (ISBT) currently recognizes 36 major blood group systems, including 346 red blood cell (RBC) antigens, 45 genes, and 1,802 alleles ${ }^{[1,2]}$. The molecular bases of almost all blood group antigen systems have been determined ${ }^{[3]}$. During the past 10 years, DNA based genotyping methods have been developed to complement routine serological typing for clinically significant blood groups in transfusion medicine ${ }^{[4,5]}$. Blood group genotyping is used in many aspects, such as blood typing of donors for alloimmunized patients, determining the blood group of a recently transfused patient or antiglobulin test positive blood sample, as well as screening donors for rare blood groups ${ }^{[6]}$.

*Correspondence to: Tongmao Zhao, Ph.D. National Institutes of Health, Bethesda, Maryland, 20852, USA. E-mail:tomhla@163.com.

The authors declared no conflict of interests.
Reference DNAs are required for the development and validation of blood group genotyping methods, and for their optimal use in routine practice. However, the distribution of blood groups can differ widely between different ethnic groups. For example, the frequency of $\mathrm{K}$ antigens is $9 \%$ in Caucasians and $2 \%$ in Blacks, while it is almost zero in Chinese. The incidence of $\mathrm{Fy}(\mathrm{a}-\mathrm{b}-)$ phenotype is rare in Caucasians, but is $68 \%$ in Blacks and zero in Chinese, respectively. In contrast, Mur antigen, which does not present in Caucasians or Blacks, has a higher frequency in South China. Therefore, it is necessary to establish a set of reference DNA that is suitable for the Chinese population. In this study, a total of 100 genomic DNA samples obtained from Chinese, Caucasian, and Blacks were typed for $31 \mathrm{RBC}$ antigens of 13 blood systems using a multiplex polymerase chain reaction (PCR) genotyping assay. Finally, nine DNA samples were selected to set up a panel of reference DNA. 


\section{MATERIALS AND METHODS}

\section{Genomic DNA samples}

Sixty sets of purified genomic DNAs were obtained from the Coriell Institute for Medical Research ${ }^{[7]}$ and International Histocompatibility Working Group (IHWG) Cell and DNA Bank ${ }^{[8]}$, of which 30 were Caucasian and 20(30?) were Black ethnic background. Forty EDTA-anticoagulated whole blood specimens were collected from the Li minority living in Hainan Province, China. DNA was extracted using a DNA purification kit (G\&T Biotech, Rockville, MD, USA). The concentration of DNA was estimated using a NanoDrop 2000 Spectrophotometer (Thermo Fisher Scientific, Wilmington, DE, USA) and DNA samples were kept at $-20^{\circ} \mathrm{C}$ for long term storage.

\section{Multiplex PCR genotyping assay}

Based on the publications ${ }^{[9,10]}$, a multiplex PCR assay was designed to identify 19 SNPs of 31 RBC antigens in six reaction mixes. The PCR mixes and the length of amplified products are shown in Table 1. The assay determines 31 common and high-frequency-alleles (Table 2): MNS1, MNS2, MNS3, MNS4, and MNS10; LU1, LU2, LU18 and LU19; KEL1 and $K E L 2 ; F Y 1, F Y 2$, and FY; JK1 and JK2;DII and DI2; $Y T 1$ and $Y T 2 ; S c 1$ and $S c 2 ; D O 1$ and $D O 2 ; C O 1$ and CO2; KN1 and KN2; INI and IN2; VEL. The assay was validated with 40 known alleles previously determined by sequencing analysis. The sequences of polymorphism-specific primers used in the multiplex PCR was taken from publications with a few changes of reverse primers to ensure the length of the PCR

Table 1 PCR reaction mixes and product sizes

\begin{tabular}{|c|c|c|c|c|c|c|c|c|c|c|c|}
\hline \multicolumn{2}{|c|}{ Mix A } & \multicolumn{2}{|c|}{ Mix B } & \multicolumn{2}{|c|}{ Mix C } & \multicolumn{2}{|c|}{ Mix D } & \multicolumn{2}{|c|}{ Mix E } & \multicolumn{2}{|c|}{ Mix F } \\
\hline Allele & Size (bp) & Allele & Size (bp) & Allele & Size (bp) & Allele & Size (bp) & Allele & Size (bp) & Allele & Size (bp) \\
\hline$F y^{b} / F y$ & 711 & $D o^{a}$ & 477 & $M$ & 576 & $N$ & 576 & $I^{a}$ & 512 & $I n^{b}$ & 512 \\
\hline$D o^{b}$ & 477 & $k$ & 352 & $\operatorname{Vel}(-)$ & 470 & $\operatorname{Vel}(+)$ & 483 & $F y^{a}$ & 446 & $F y^{b}$ & 446 \\
\hline$K$ & 352 & $J k^{b}$ & 237 & $D i^{b}$ & 400 & $D i^{a}$ & 379 & $\mathrm{Co}^{b}$ & 291 & $\mathrm{Co}^{a}$ & 291 \\
\hline$J k^{a}$ & 237 & $L u^{a}$ & 170 & $K n^{a}$ & 298 & $K n^{b}$ & 298 & $Y t^{a}$ & 213 & $Y t^{b}$ & 213 \\
\hline$L u^{b}$ & 170 & & & $S$ & 215 & $s$ & 215 & $\operatorname{Mur}(-)$ & 144 & $\operatorname{Mur}(+)$ & 144 \\
\hline
\end{tabular}

products. All PCR mixes were prepared in advance as a "ready-to-use" kit (G\&T Biotech, Rockville, MD, USA). Eight microliters of mixes were stored at $-20^{\circ} \mathrm{C}$ under $10 \mu \mathrm{L}$ of mineral oil in 96 well PCR plates. The multiplex PCR was carried out with $1 \mu \mathrm{L}$ of purified DNA sample $(0.10-0.20 \mu \mathrm{g}), 1 \mu \mathrm{L}$ of diluted Taq polymerase (0.25-0.33 units), and $8 \mu \mathrm{L} \mathrm{PCR} \mathrm{mix} \mathrm{[10} \mathrm{mmol/L}$

Table 2 The alleles and SNPs detected by multiplex PCR genotyping

\begin{tabular}{|c|c|c|c|}
\hline ISBT\# & Blood group system & Allele & SNP \\
\hline 002 & MNS & $M / N$ & $59 \mathrm{C} \rightarrow \mathrm{T}, 71 \mathrm{G} \rightarrow \mathrm{A}, 72 \mathrm{~T} \rightarrow \mathrm{G}$ \\
\hline 002 & MNS & $S / s$ & $143 \mathrm{~T} \rightarrow \mathrm{C}$ \\
\hline 002 & MNS & $M u r+/ M u r-$ & $\mathrm{B}-\mathrm{A}-\mathrm{B}$ \\
\hline 005 & LU & $L u^{a} / L u^{b}$ & $230 \mathrm{~A} \rightarrow \mathrm{G}$ \\
\hline 005 & LU & $A u^{a} / A u^{b}$ & $1615 \mathrm{~A} \rightarrow \mathrm{G}$ \\
\hline 006 & KEL & $K / k$ & $698 \mathrm{~T} \rightarrow \mathrm{C}$ \\
\hline 008 & FY & $F y^{a} / F y^{b}$ & $125 \mathrm{G} \rightarrow \mathrm{A}$ \\
\hline 005 & FY & $F y^{b} / F y$ & Promoter $-67 \mathrm{t} \rightarrow \mathrm{c}$ \\
\hline 009 & $\mathrm{JK}$ & $J k^{a} / J k^{b}$ & $838 \mathrm{G} \rightarrow \mathrm{A}$ \\
\hline 010 & DI & $D i^{a} / D i^{b}$ & $2561 \mathrm{~T} \rightarrow \mathrm{C}$ \\
\hline 011 & YT & $Y t^{a} / Y t^{b}$ & $1057 \mathrm{C} \rightarrow \mathrm{A}$ \\
\hline 013 & $\mathrm{SC}$ & $S c 1 / S c 2$ & $169 \mathrm{G} \rightarrow \mathrm{A}$ \\
\hline 014 & DO & $D o^{a} / D o^{b}$ & $793 \mathrm{~A} \rightarrow \mathrm{G}$ \\
\hline 015 & $\mathrm{CO}$ & $\mathrm{Co}^{a} / \mathrm{Co}^{b}$ & $134 \mathrm{C} \rightarrow \mathrm{T}$ \\
\hline 022 & $\mathrm{KN}$ & $K n^{a} / K n^{b}$ & $4708 \mathrm{G} \rightarrow \mathrm{A}$ \\
\hline 023 & IN & $\operatorname{In}^{a} / \operatorname{In}^{b}$ & $252 \mathrm{C} \rightarrow \mathrm{G}$ \\
\hline 034 & VEL & $\mathrm{Vel}+/ \mathrm{Vel}-$ & 68-80del. \\
\hline
\end{tabular}

Tris- $\mathrm{HCl}$ (pH8.3), $50 \mathrm{mmol} / \mathrm{L} \mathrm{KCl}, 1.5 \mathrm{mmol} / \mathrm{L} \mathrm{MgCl}_{2}$, $0.001 \%$ (wt/vol) gelatin, $0.2 \mathrm{mmol} / \mathrm{L}$ dNTPs, 0.5 $\mu_{\mathrm{mol}} / \mathrm{L}$ of each forward and reverse primer] in a final $10 \mu \mathrm{L}$ reaction volume. After denaturation for $5 \mathrm{~min}$ at $95^{\circ} \mathrm{C}$, samples were subjected to 30 cycles of PCR in a DNA thermal cycler. Each cycle included $95{ }^{\circ} \mathrm{C}$ for 30 secs, $60^{\circ} \mathrm{C}$ for $30 \mathrm{secs}$, and $72^{\circ} \mathrm{C}$ for $1.5 \mathrm{~min}$ followed by a final extension at $72^{\circ} \mathrm{C}$ for 5 min. PCR products were analyzed by electrophoresis on a $3 \%$ agarose gel containing $0.5 \mu \mathrm{g}$ of ethidium bromide $/ \mathrm{mL}$ and visualized with UV transilluminator.

\section{Serological Typing}

All the red cells of 40 blood samples collected from the Li minority were serologically phenotyped by agglutination testing using monoclonal antibodies or alloantibodies (Jiangsu LiBio Medicine Biotechnology Co., Ltd., Jiangsu, China). The following 17 RBC antigens were determined: A, B, D, C, c, E, e, M, N, S, s, Mur, Le ${ }^{\mathrm{a}}, \mathrm{Le}^{\mathrm{b}}, \mathrm{Fy}^{\mathrm{a}}, \mathrm{Fy}^{\mathrm{b}}$, and $\mathrm{Di}^{\mathrm{a}}$.

\section{RESULTS}

Forty blood samples were serologically phenotyped for M, N, S, s, Mur, $\mathrm{Le}^{\mathrm{a}}, \mathrm{Le}^{\mathrm{b}}, \mathrm{Fy}^{\mathrm{a}}, \mathrm{Fy}^{\mathrm{b}}$, and $\mathrm{Di}^{\mathrm{a}}$ antigens. There was complete concordance with the DNA 
genotyping results. Fig. 1 shows genotyping results of some samples that have predicted lower incidence phenotypes.

In 100 DNA samples tested, the following lower incidence phenotypes were detected: $3 \mathrm{Lu}(\mathrm{a}+\mathrm{b}+)$, $3 \mathrm{Au}(\mathrm{a}-\mathrm{b}+), 3 \mathrm{Kk}, 4$ Fy (a-b-), $4 \mathrm{Jk}(\mathrm{a}+\mathrm{b}-), 1 \mathrm{Di}$ $(a+b+), 3 \mathrm{Yt}(\mathrm{a}+\mathrm{b}+), 1 \mathrm{Sc}(1+2+), 8 \mathrm{Co}(\mathrm{a}+\mathrm{b}+), 4 \mathrm{Kn}$ $(a+b+)$, and 18 Mur positive. It was noticed that all Mur positive samples were from the Li minority living in southern China. The Mur antigen frequency was as high as $36 \%$ in this ethnic group. Unfortunately, no control samples for $\mathrm{In}^{\mathrm{a}}$ positive or Vel negative were
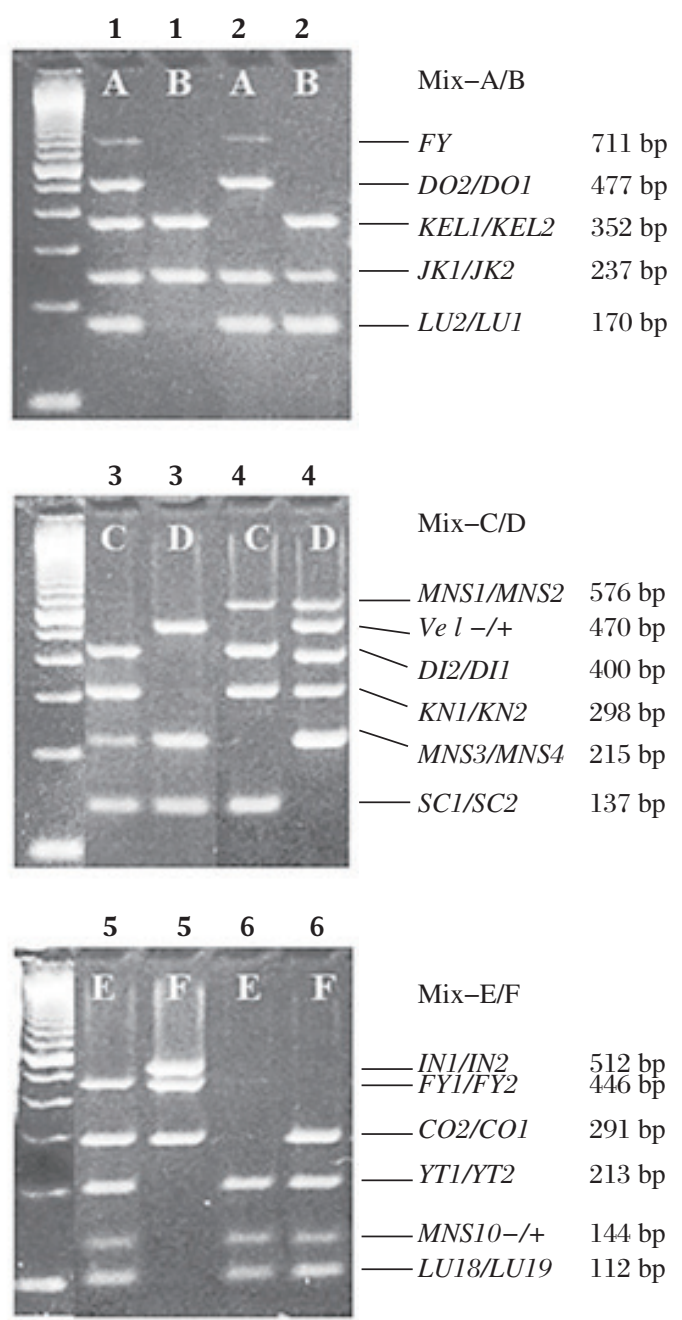

Fig. 1 Ethidium bromide stained agarose gels of multiplex PCR RBC genotyping. Example for typing results of six individuals carrying rare alleles (columns: 1-6). Each of the six reaction mixes (Mix-A, B, C, D, E, F) are designed to detect five to seven alleles. Designations of the alleles and the sizes of the PCR-products are indicated on the right border. A size marker is running in the left lane. The predicted phenotypes with lower incidence are shown as follows: sample 1 and 2, Fy (a-b-); sample 1, Kk; sample 2, Lu (a+b+); sample 3, Sc (1+2+); sample 4, Di (a+b+), Kn (a+b+); sample 5, Co (a+b+), and sample 6, $\mathrm{Yt}(\mathrm{a}+\mathrm{b}+), \mathrm{Au}(\mathrm{a}+\mathrm{b}+)$. available.

Nine DNA samples were selected to make up a minimum number of reference DNA that carried 29 alleles of 13 blood group systems (Fig. 2, Table 3).

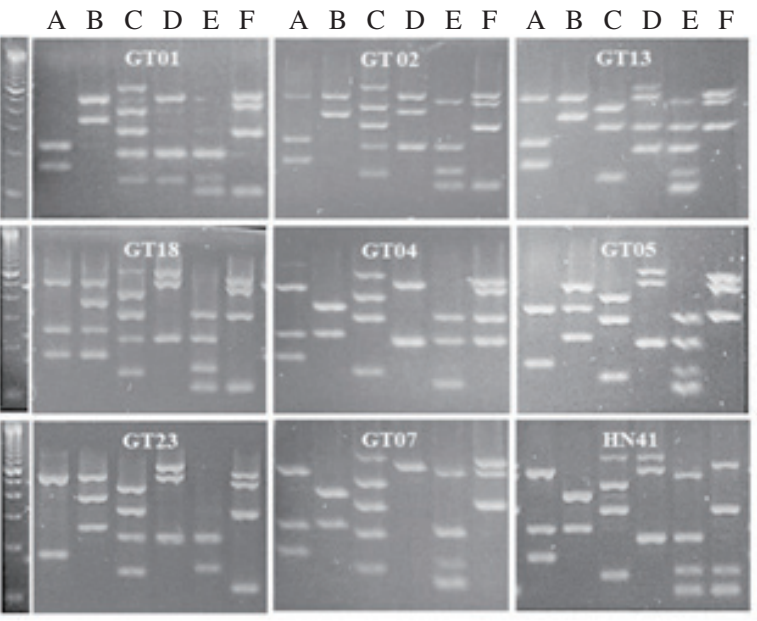

Fig. 2 Genotyping results of nine reference DNA sample. The top letters indicate six PCR reaction mixes.

\section{DISCUSSION}

In 2011 Jungbauer et al. ${ }^{[9]}$ reported a high-throughput multiplex PCR genotyping method for 35 red blood cell antigens. This method has the advantages of being easy to perform, being lower cost than serological typing, having a flexible design of the allele combination to be tested, and not requiring particularly expensive special equipment, so it is applicable to the transfusion department of the hospitals. Based on the principle of this method, we designed a novel multiplex PCR genotyping assay that is more suitable for the Chinese population. In comparison with Jungbauer's method, the high-incidence antigen LU8, KEL4, KEL7, KEL11, DI4 and the low-incidence antigen LU14, KEL3, KEL6, KEL17, KEL21, FY0, FYX, DI3 were excluded, but the Mur antigen was included. Mur is a common antigen among Asians. The frequency of antigen Mur is about $9 \%$ in Guangdong province $^{[10]}$ and $7.3 \%$ in Taiwan ${ }^{[11]}$, while about one third of Li minorities investigated in this study carry this antigen. As an irregular antibody, anti-Mur often causes the problems in blood grouping.

To date, a number of blood group genotyping technologies have been established. In order to validate the reliability of the testing reagents, evaluate the proficiency of genotyping and conduct external quality assessments, the standard DNAs as a reference were required. The AABB publication, "Standards for molecular testing for red cell, platelet, and neutrophil 
Table 3 A panel of reference DNA

\begin{tabular}{|c|c|c|c|c|c|c|c|c|c|c|c|c|c|c|c|c|}
\hline & & MNS & & & & KEL & $\mathrm{FY}$ & $\mathrm{JK}$ & DI & YT & $\mathrm{SC}$ & $\mathrm{DO}$ & $\mathrm{CO}$ & $\mathrm{KN}$ & IN & VEL \\
\hline ID & $\mathrm{MN}$ & Ss & Mur & $\mathrm{Lu}$ & $\mathrm{Au}$ & $\mathrm{Kk}$ & Fy & $\mathrm{Jk}$ & Di & $\mathrm{Yt}$ & $\mathrm{Sc}$ & Do & Co & $\mathrm{Kn}$ & In & Vel \\
\hline GT01 & $\mathrm{M}$ & Ss & - & $a-b+$ & $a+b+$ & $\mathrm{kk}$ & $a-b+$ & $a+b-$ & $a-b+$ & $a+b-$ & $1+2+$ & $a+b-$ & $a+b-$ & $a+b-$ & $a-b+$ & + \\
\hline GT02 & $\mathrm{MN}$ & Ss & - & $a-b+$ & $a+b+$ & $\mathrm{kk}$ & $a+b+$ & $a+b-$ & $a+b+$ & $a+b-$ & $1+2-$ & $a+b+$ & $a+b-$ & $a+b-$ & $a-b+$ & + \\
\hline GT13 & $\mathrm{N}$ & ss & - & $a-b+$ & $a+b-$ & $\mathrm{kk}$ & $a+b+$ & $a+b-$ & $a-b+$ & $a+b-$ & $1+2-$ & $a+b+$ & $a+b+$ & $a+b+$ & $a-b+$ & + \\
\hline GT18 & $\mathrm{MN}$ & Ss & - & $a+b+$ & $a+b+$ & $\mathrm{kk}$ & $a-b+$ & $a+b+$ & $a-b+$ & $a+b-$ & $1+2-$ & $a+b+$ & $a+b+$ & $a+b-$ & $a-b+$ & + \\
\hline GT04 & $\mathrm{M}$ & ss & - & $a-b+$ & $a+b-$ & $\mathrm{kk}$ & $\mathrm{Fy}, \mathrm{b}+$ & $a+b+$ & $a-b+$ & $a+b+$ & $1+2-$ & $a-b+$ & $a+b+$ & $a+b-$ & $a-b+$ & + \\
\hline GT23 & $\mathrm{N}$ & Ss & - & $a-b+$ & $a-b+$ & $\mathrm{kk}$ & $a-b+$ & $a-b+$ & $a-b+$ & $a+b-$ & $1+2-$ & $a+b+$ & $a+b-$ & $a+b-$ & $a-b+$ & + \\
\hline GT07 & M & SS & - & $a-b+$ & $a+b-$ & $\mathrm{kk}$ & $a+b+$ & $a+b+$ & $a-b+$ & $a+b-$ & $1+2-$ & $a-b+$ & $a+b-$ & $a+b-$ & $a-b+$ & + \\
\hline HN41 & $\mathrm{MN}$ & ss & + & $a-b+$ & $\mathrm{a}+\mathrm{b}+$ & $\mathrm{kk}$ & $a+b-$ & $a+b+$ & $a-b+$ & $a+b-$ & $1+2-$ & $a-b+$ & $a+b-$ & $a+b-$ & $a-b+$ & + \\
\hline
\end{tabular}

antigens" has recommended alleles from 17 blood groups for reference standards ${ }^{[12]}$. The proficiency exchange from the Consortium for Blood Group Genes (CBGG) includes 16 alleles from 5 blood group systems ${ }^{[13]}$. ISBT international workshop on genotyping reported test results on alleles from 11 blood group systems ${ }^{[14]}$. Proposed WHO reference reagents include 4 samples from Caucasians and Blacks typed for 7 blood group systems ${ }^{[15]}$. FDA (Food and Drug Administration) plans to develop reference panels that are designed to include about 90 genotypes of the blood group systems ${ }^{[15]}$.

Considering the differences in blood group distribution and the genomic sequence in different ethnic groups, it is necessary to establish a set of DNA reference materials suitable for Chinese people. These DNA samples can be collected from Chinese individuals who carry special alleles, and can also be picked from established human cell lines. In the present study, a panel reference DNA consists of nine DNA samples that carry 29 alleles of 13 blood group systems, including clinically significant alleles and common $\mathrm{RBC}$ antigens in the Chinese population. In the future, we will establish lymphoblastoid cell lines by Epstein Barr virus transformation for individuals carrying specific alleles to ensure a sustainable DNA source.

According to the project to develop comprehensive reference panels for blood group genotyping for international accreditation and distribution initiated by the Center for Biologics Evaluation and Research (CBER) of the FDA, the reference blood group genotypes should be examined or verified using at least two molecular methods ${ }^{[15]}$. We are currently using sequencing analysis to comply with this, and will report the results in a separate article.

\section{References}

[1] Storry JR, Castilho L, Chen Q, et al. International society of blood transfusion working party on red cell immunogenetics and terminology: report of the Seoul and London meetings. ISBT Science Series, 2016, 11: 118-22.

[2] The Blood Group Antigen Gene Mutation Database. https://www.ncbi.nlm.nih.gov/projects/gv/mhc/xslcgi. cgi?cmd=bgmut/home.[2017-11-23].

[3] Denomme GA. Molecular basis of blood group expression. Transfus Apher Sci, 2011, 44(1): 53-63.

[4] Monteiro F, Tavares G, Ferreira M, et al. Technologies involved in molecular blood group genotyping. ISBT Science Series, 2011, 6: 1-6.

[5] Reid ME, Denomme GA. DNA-based methods in the immunohematology reference laboratory. Transfus Apher Sci, 2011, 44(1): 65-72.

[6] Flegel WA, Gottschall JL, Denomme GA. Implementing mass-scale red cell genotyping at a blood center. Transfusion, 2015, 55(11): 2610-5.

[7] Coriell Institute for Medical Research. http://coriell.org/. [2017-11-23].

[8] International Histocompatibility Working Group. https:// www.fredhutch.org/. [2017-11-23].

[9] Jungbauer C, Hobel CM, Schwartz DWM, et al. Highthroughput multiplex PCR genotyping for 35 red blood cell antigens in blood donors. Vox Sang, 2012, 102(3):234-42.

[10] Wei L, Shan ZG, Flower RL, et al. The distribution of MNS hybrid glycophorins with Mur antigen expression in Chinese donors including identification of a novel GYP.Bun allele. Vox Sang, 2016, 111(3):308-14.

[11] Yang CA, Lin JA, Chang CW, et al. Selection of GP. Mur antigen-negative RBC for blood recipients with anti-'Mia' records decreases transfusion reaction rates in Taiwan. Transfus Med, 2016, 26(5):349-54.

[12] The AABB standard program committee. Standards for molecular testing for red cell, platelet, and neutrophil antigens, 3rd edition. Bethesda, 2016:7-9.

[13] Delaney M. Proficiency testing for blood group genotyping. Transfusion, 2013, 53(11 Suppl 2):2847-9.

[14] Boyle J, Thorpe SJ, Hawkins JR, et al. International reference reagents to standardise blood group genotyping: evaluation of candidate preparations in an international collaborative study. Vox Sang, 2013, 104(2):144-52.

[15] Liu Z. Establishment of reference panels for blood group genotyping tests. https://www.fda.gov/BiologicsBloodVaccines/ScienceResearch/BiologicsResearchAreas/ ucm352425.htm. [2017-11-23].

(Received 22 November 2017, Revised 10 December 2017, Accepted 14 December 2017) 